\title{
Effects of Body Temperature on Neural Activity in the Hippocampus: Regulation of Resting Membrane Potentials by Transient Receptor Potential Vanilloid 4
}

\author{
Koji Shibasaki, ${ }^{1,2}$ Makoto Suzuki, ${ }^{3}$ Atsuko Mizuno, ${ }^{3}$ and Makoto Tominaga ${ }^{1,2}$ \\ ${ }^{1}$ Section of Cell Signaling, Okazaki Institute for Integrative Bioscience, National Institutes of Natural Sciences, Okazaki 444-8787, Japan, ${ }^{2}$ Department of \\ Physiological Sciences, The Graduate University for Advanced Studies, Okazaki 444-8585, Japan, and 3Department of Pharmacology, Jichi Medical School, \\ Minamikawachi, Tochigi 329-0498, Japan
}

\begin{abstract}
Physiological body temperature is an important determinant for neural functions, and it is well established that changes in temperature have dynamic influences on hippocampal neural activities. However, the detailed molecular mechanisms have never been clarified. Here, we show that hippocampal neurons express functional transient receptor potential vanilloid 4 (TRPV4), one of the thermosensitive TRP (transient receptor potential) channels, and that TRPV4 is constitutively active at physiological temperature. Activation of TRPV4 at $37^{\circ} \mathrm{C}$ depolarized the resting membrane potential in hippocampal neurons by allowing cation influx, which was observed in wild-type (WT) neurons, but not in TRPV4-deficient (TRPV4KO) cells, although dendritic morphology, synaptic marker clustering, and synaptic currents were indistinguishable between the two genotypes. Furthermore, current injection studies revealed that TRPV4KO neurons required larger depolarization to evoke firing, equivalent to WT neurons, indicating that TRPV4 is a key regulator for hippocampal neural excitabilities. We conclude that TRPV4 is activated by physiological temperature in hippocampal neurons and thereby controls their excitability.
\end{abstract}

Key words: TRPV4; TRP channel; hippocampus; neural activity; synapse; body temperature

\section{Introduction}

The hippocampus contains neural circuitry that is crucial for higher brain functions, such as learning and memory (Malenka and Nicoll, 1999). The neurons that form the circuits in the hippocampus require transmembrane cation influx for their depolarization and the generation of action potentials (Nicholls et al., 2001; Nicoll, 2003). Many kinds of ion channels and receptors, such as voltage-gated $\mathrm{Na}^{+}$channels, voltage-gated $\mathrm{Ca}^{2+}$ channels (Trimmer, 1998), and glutamate receptors, contribute to membrane depolarization (Nicholls et al., 2001). It has recently been reported that ASICs (acid-sensing ion channels) depolarize neurons by relieving the $\mathrm{Mg}^{2+}$ block of NMDA receptors (Wemmie et al., 2002). Thus, it is possible that other ion channels might also be involved in the modulation of membrane potentials in neurons. In fact, it is reported that a nociceptor-specific cation

Received June 11, 2006; revised Jan. 5, 2007; accepted Jan. 9, 2007.

This work was supported by the Grant of the Tokai Science Academy (K.S.) and by the Ministry of Education Culture, Sports, Science and Technology, Japan, and the Astra Zeneca Foundation (M.T.). We thank Drs. I. Jung, N. Murayama, and K. Togashi for technical assistance; Drs. J. Nabekura, K. Yamada, S.-I. Watanabe, F. Tamalu, K. Ono, and T. Fukumi-Tominaga for discussion; Drs. R. Nicoll and J. S. Trimmer for critical reading of this manuscript; and Dr. K. Ikenaka and his laboratory members for encouragement. The monoclonal antibodies GAD65, developed by D. I. Gottlieb, neuofilament, developed by T. M. Jessel, and Mac1, developed by T. A. Springer, were obtained from the Developmental Studies Hybridoma Bank maintained by the University of lowa, Department of Biological Sciences.

Correspondence should be addressed to Makoto Tominaga, Section of Cell Signaling, Okazaki Institute for Integrative Bioscience, National Institutes of Natural Sciences, Okazaki, Aichi 444-8787, Japan. E-mail: tominaga@nips.ac.jp.

DOI:10.1523/JNEUROSCI.4284-06.2007

Copyright $\odot 2007$ Society for Neuroscience $\quad$ 0270-6474/07/271566-10\$15.00/0 channel, transient receptor potential vanilloid 1 (TRPV1), which was first found to be a receptor for capsaicin (Caterina et al., 1997; Tominaga et al., 1998), modulated presynaptic dopamine release in the substantia nigra through its activation by anandamide (Marinelli et al., 2003). These results strongly suggest that other thermosensitive transient receptor potential (TRP) channels might have similar abilities to regulate synaptic activity in the brain, in addition to their basal functions.

TRPV4 is a nonselective cation channel, first described as an osmosensor detecting hypotonic stimuli, and shares $40 \%$ amino acid identity with TRPV1 (Liedtke et al., 2000; Stortmann et al., 2000; Wissenbach et al., 2000; Nilius et al., 2001). TRPV4 can also be activated by heat $\left(>27-34^{\circ} \mathrm{C}\right)$, the phorbol ester derivative $4 \alpha$-phorbol-12,13-didecanoate ( $4 \alpha$-PDD), or lipids downstream of arachidonic acid metabolism (Guler et al., 2002; Watanabe et al., 2002a,b, 2003). The expression of TRPV4 in kidney, cochlea, sweat glands, sensory nerve terminals, and osmosensory cells in the brain is in agreement with the osmosensing and/or mechanosensing function of TRPV4 (Delany et al., 2001; AlessandriHaber et al., 2003; Mutai and Heller, 2003; Nilius et al., 2004). Mice lacking this gene exhibited defects in high-threshold mechanosensation and pressure sensation (Suzuki et al., 2003). TRPV4 was reported to be necessary for the response to changes in osmotic pressure and to function as an osmotic sensor in the CNS (Liedtke and Friedman, 2003; Mizuno et al., 2003). Although the role of TRPV4 in sensation has been analyzed in detail, its possible involvement in brain functions remains to be elucidated. Be- 
cause TRPV4 is activated at physiological core body temperature, we speculated that TRPV4 might be constitutively active under normothermic conditions, which would suggest involvement in neural excitability.

It is well known that small changes in brain temperature (as little as $2-3^{\circ} \mathrm{C}$ ) affect brain functions and neuronal properties (Hodgkin and Katz, 1949; Ritchie and Straub, 1956; Schiff and Somjen, 1985; Moser et al., 1993). Therefore, heat-sensitive molecular components seem to be essential for brain functions at physiological temperature, although the molecular nature remains to be clarified. In this study, we examined the significance of TRPV4 activation at physiological temperature for regulation of neural activities.

\section{Materials and Methods}

Animals. TRPV4-deficient (TRPV4KO) mice were generated by crossing heterozygous mice, and the genotypes were determined by PCR as described previously (Mizuno et al., 2003; Suzuki et al., 2003). We used the C57BL/6Cr strain of mice as the wild-type (WT) control. All animal care and experimental procedures were performed according to National Institutes of Health and National Institute for Physiological Sciences guidelines.

Cell culture of dissociated hippocampal neurons. Mouse hippocampal neurons were prepared using a modified protocol from rat hippocampal culture methods (Goslin et al., 1998; Lim et al., 2000). In brief, hippocampi were dissected from postnatal day 0 (P0) pups and dissociated using trypsin $(0.25 \%)$ and trituration. Neurons were plated on poly-Dlysine-coated coverslips ( $15 \mathrm{~mm}$ round; Assistant, Sondheim, Germany) at a final density of $1-5 \times 10^{5}$ cells/coverslips in Neurobasal medium (Invitrogen, Carlsbad, CA) with B27 supplement (Invitrogen). After $12 \mathrm{~h}$, coverslips were immersed in astrocyte-conditioned medium (Neurobasal medium with B27 supplement). To prevent overgrowth of glia, neuron cultures were treated with cytosine arabinoside $(5 \mu \mathrm{M}$; Calbiochem, La Jolla, CA) after incubation for $3 \mathrm{~d}$ in vitro (DIV).

Cell culture of hippocampal or cortical astrocytes. Astrocytes were prepared from newborn mice (P0-P2). In brief, dissected cortical hemispheres or hippocampi were triturated using a wide-pore Pasteur pipette and filtered through $100 \mu \mathrm{m}$ pore nylon mesh. Cells were resuspended in $10 \mathrm{ml}$ of MEM containing $10 \%(\mathrm{v} / \mathrm{v})$ donor horse serum, $0.6 \%(\mathrm{w} / \mathrm{v})$ glucose, and $1 \mu \mathrm{g} / \mathrm{ml}$ penicillin/streptomycin, plated on $10 \mathrm{~cm}$ plastic tissue culture dishes at 300,000 cells/dish, and cultured for 7-10 d in a humidified $\mathrm{CO}_{2}$ incubator at $37^{\circ} \mathrm{C}$. For reverse transcription (RT)-PCR experiments (supplemental Fig. 1, available at www.jneurosci.org as supplemental material), hippocampal astrocytes were plated on $10 \mathrm{~cm}$ dishes as described above. When the astrocyte cultures reached $80 \%$ confluence, the cells were harvested, resuspended in medium supplemented with $10 \%$ dimethylsulfoxide ( $1 \mathrm{ml}$ per $10 \mathrm{~cm}$ dish), frozen in $1 \mathrm{ml}$ aliquots at $-80^{\circ} \mathrm{C}$, and stored at either $-80^{\circ} \mathrm{C}$ or in liquid nitrogen. To prepare astrocyte-conditioned medium, revived astrocytes were plated on $10 \mathrm{~cm}$ dishes at 300,000 cells/dish (around five dishes per $1 \mathrm{ml}$ aliquot of frozen cells) coated with $25 \mu \mathrm{g} / \mathrm{ml}$ poly-L-lysine. Once the astrocyte cultures reached $80 \%$ confluence, the medium was completely replaced with Neurobasal medium with B27 supplement. At days 7 and 14, the "conditioned" media were collected, centrifuged at $1000 \times g$ for $15 \mathrm{~min}$, filtered with a $0.2 \mu \mathrm{m}$ pore filter unit, and combined. Astrocyte conditioned media were used for hippocampal neuron cultures as described above.

Semiquantitative reverse transcription-PCR. Total RNA was prepared from various tissues of 8 -week-old mice or cultured cells using Trizol reagent (Invitrogen). Total RNA ( $1 \mu \mathrm{g})$ was converted to cDNA using SuperScriptII RNaseH (-) Reverse Transcriptase (Invitrogen). Fragments of mouse TRPV4 or $\beta$-actin were PCR-amplified from the cDNA with primers $\left(5^{\prime}\right.$-mTRPV4 and $3^{\prime}$-mTRPV4 primer sets: $5^{\prime}$ CCGTGCACCAACATGAAGGTC-3' $5^{\prime}$-TTGTTCAGCTCCACTACGCGG-3'), (5'- $\beta$-actin and $3^{\prime}-\beta$-actin primer sets: $5^{\prime}$-CAACGGCTCCGGCATGTGC- $3^{\prime} ， 5^{\prime}$-CTCTTGCTCTGGGCCTCG-3' ${ }^{\prime}$ ). PCR experiments without reverse transcriptase were done to check DNA contamination in the total RNA samples.
Immunohistochemical and in situ hybridization analyses. Immunohistochemistry and in situ hybridization were performed as described previously (Shibasaki et al., 2004, 2007). Briefly, adult mice (8 weeks of age) were perfused with ice-cold $4 \%$ paraformaldehyde (PFA) into their left ventricles. Brains were postfixed with $4 \%$ PFA for $2 \mathrm{~h}$ at $4^{\circ} \mathrm{C}$, treated with 20 and 30\% sucrose for several hours, embedded in OCT compounds (Sakura, Tokyo, Japan), and then sectioned (10-14 $\mu \mathrm{m}$ thickness). Digoxigenin-labeled antisense/sense probes were used for in situ hybridization of TRPV4. The fragment of mouse TRPV $4 \mathrm{cDNA}$ was obtained by PCR (5'-mTRPV4-N and 3'-mTRPV4-N primer sets: 5' -CTGGAGATGAGAGTGGTACCT- ${ }^{\prime}$, $5^{\prime}$ - -TCTACTGGTACCGTGTGTGTCTA$3^{\prime}$ ), and the $1400 \mathrm{bp}$ fragment was subcloned into pBluescriptSKII (+) by $B a m \mathrm{HI}$ and $\mathrm{XbaI}$ sites. After we linearized the plasmid (antisense, $B a m \mathrm{HI}$; sense, $\mathrm{XbaI}$ ), the digoxigenin-labeled antisense/sense probes were synthesized by RNA polymerase (antisense, T3 RNA polymerase; sense, T7 RNA polymerase). For immunostaining, the samples were preincubated with a blocking solution (3\% bovine serum albumin and $0.3 \%$ Triton X-100 in PBS) for $1 \mathrm{~h}$, and then incubated overnight at $4^{\circ} \mathrm{C}$ in blocking solutions with the following antibodies: rabbit polyclonal antisynapsin-I antibody (1:200; Sigma, St. Louis, MO), mouse antipostsynaptic density-95 (PSD-95) antibody (clone K28/43; 1:200; Upstate, Lake Placid, NY), mouse anti-NMDAR1 (NMDA receptor 1) receptor antibody (1:1000; Chemicon, Temecula, CA), rabbit polyclonal anti-glial fibrillary acidic protein (GFAP) antibody (1:500; Sigma), and Alexa 633-conjugated anti-phalloidin antibody (1:1500; Invitrogen). A mouse monoclonal antibody, anti-GAD65 (1:200), anti-neurofilament (1:500), and anti-Mac1 (1:20) were obtained from the Developmental Studies Hybridoma Bank (Iowa City, IA). To check the cell populations in the hippocampal neuron or astrocyte culture, we used the following neuronal markers; anti-neurofilament (neurons), anti-GFAP (astrocytes), anti-O4 (oligodendrocytes), and anti-Mac1 (microglias) antibodies. For ectopic expression of TRPV4-enhanced green fluorescent protein (EGFP) fusion protein, we transfected the plasmid (TRPV4-EGFP/pEGFPC3, which has the full coding sequence of mouse TRPV4 in the vector with XhoI and EcoRI sites) into 19 DIV hippocampal neurons using Lipofectamine 2000 reagent (Invitrogen). Two days after transfection, we fixed and stained the transfected neurons. To characterize dendritic branching and spine density of the transfected neurons, we measured dendritic length (three dendrites per cell), and counted the numbers of spines and dendritic branches. We calculated the numbers per $10 \mu \mathrm{m}$ (for spine density) or $100 \mu \mathrm{m}$ (for dendritic branching). For the quantification, we counted 178-244 cells.

Immunoblot analysis. To make anti-rat TRPV4 (TRPV4N) antibody, a peptide encoding the predicted amino terminus of TRPV4 (DPGDGPRAAPGEVAE) was coupled to keyhole limpet hemocyanin via a carboxyl-terminal cysteine and used to immunize rabbits. To examine the quality of TRPV4N antibody, anti-TRPV4 antibody from Alomone Labs (Jerusalem, Israel) was also used. Membrane fractions were prepared by ultracentrifugation $\left(100,000 \times g ; 1 \mathrm{~h} ; 4^{\circ} \mathrm{C}\right)$ from whole-cell lysates according to a previously reported protocol with slight modification (Maletic-Savatic et al., 1995). Proteins from membrane fraction were separated by $8 \%$ SDS-PAGE, and the proteins were transferred to polyvinylidene difluoride membranes. Membranes were blotted with TRPV4N antibody or rabbit polyclonal anti-TRPV4 antibody (Alomone Labs), followed by blotting with HRP-conjugated anti-rabbit IgG (Cell Signaling Technology, Beverly, MA) antibody. ECL detection kit and Hyperfilm (Amersham Biosciences, Buckinghamshire, UK) were used for detection of the signal.

Fluorescent measurements and electrophysiology. Fura-2 fluorescence was measured by fura-2 AM (Invitrogen) in a standard bath solution containing the following (in mM): $140 \mathrm{NaCl}, 5 \mathrm{KCl}, 2 \mathrm{MgCl}_{2}, 2 \mathrm{CaCl}_{2}, 10$ HEPES, 10 glucose, $\mathrm{pH} 7.4$. The $340: 380 \mathrm{~nm}$ ratio was shown. Standard bath solution for the patch-clamp experiments was the same as that used in fluorescence measurements. Reversal potential was measured using voltage ramps ( -100 to $+40 \mathrm{mV}$ in $100 \mathrm{~ms}$ ). Liquid junction potentials were measured directly in separate experiments, and significant changes $(\sim 8 \mathrm{mV})$ were observed, and corrections were made for membrane potentials. Pipette solution for whole-cell recordings contained the following (in mM): $120 \mathrm{~K}$-gluconate, $20 \mathrm{KCl}, 0.5 \mathrm{EGTA}, 2 \mathrm{Mg}$-ATP, $2 \mathrm{~K}_{2}$-GTP, 
10 HEPES, pH 7.4. To identify hippocampal neuronal cell types, we added Lucifer yellow to the pipette solution, and immunostained the recorded cells with anti-GAD65. Isotonic (322 $\mathrm{mOsm} / \mathrm{kg})$ or hypotonic $(250 \mathrm{mOsm} / \mathrm{kg})$ solutions were prepared with different mannitol concentrations based on standard bath solution. Whole-cell recording data were sampled at $10 \mathrm{kHz}$ and filtered at $5 \mathrm{kHz}$ for analysis (Axon 200B amplifier with pCLAMP software; Molecular Devices, Foster City, CA). Wholecell patch-clamp recordings and $\mathrm{Ca}^{2+}$ imagings were performed on 21 DIV hippocampal neurons. All patch-clamp experiments were performed at room temperature $\left(25^{\circ} \mathrm{C}\right)$ or $37^{\circ} \mathrm{C}$. Chamber temperature was monitored with a thermocouple placed within $100 \mu \mathrm{m}$ of the patch-clamped cells. When resting membrane potentials (RMPs) were examined, we added picrotoxin $(10 \mu \mathrm{M})$ to standard bath solution to inhibit miniature IPSP, and monitored RMP 2 min after whole-cell configuration was established. For current injection experiments, we injected ectopic currents from -40 to $+220 \mathrm{pA}$ for each $600 \mathrm{~ms}$ injection sweep.

\section{Results}

TRPV4 is strongly expressed in mouse hippocampal neurons

We first screened TRPV4 mRNA expression in various mouse brain regions by RT-PCR. As first reported by Liedtke et al. (2000), we confirmed high TRPV4 mRNA expression in the choroid plexus from WT, but not from TRPV4KO mice (Fig. $1 A)$. Extending that observation, we found that TRPV4 mRNA was expressed in other brain regions including the cerebral cortex, hippocampus, and cerebel-

lum, as well as in kidney and liver, in which its expression was reported previously (Fig. $1 A$ ). We focused on TRPV4 expression in the hippocampus because the hippocampus is known to play important roles in various brain functions. To examine the expression of TRPV4 mRNA in tissue sections, we performed in situ hybridization. We first examined the specificity of the in situ probe in the kidney sections in which abundant TRPV4 expression had been reported (Liedtke et al., 2000). The antisense probe detected TRPV4 mRNA in the kidney sections from WT, but not from TRPV4KO mice (supplemental Fig. $1 A, B$, available at www.jneurosci.org as supplemental material). These results demonstrated the specificity of the antisense probe for in situ hybridization and detection of TRPV4 mRNA. Consistent with the RT-PCR results (Fig. $1 A$ ), in situ hybridization showed that the hippocampus strongly expressed TRPV4 mRNA to an extent similar to that observed in the choroid plexus (Fig. $1 B, C$ ). Such TRPV4 mRNA expression was not observed in the hippocampus from TRPV4KO mice (Fig. $1 D$ ).

Next, we examined TRPV4 protein expression in the hippocampus by immunoblotting. We confirmed the quality of our own anti-TRPV4 $\mathrm{N}$ terminus (TRPV4N) antibody in the choroid plexus in which abundant TRPV4 expression was reported previously. Both TRPV4N and commercial (Alomone Labs) antiTRPV4 antibodies clearly detected signals in the choroid plexus from WT, but not from TRPV4KO mice in the Western blots (supplemental Fig. 2, available at www.jneurosci.org as supplemental material). TRPV4 proteins were also detected in the hippocampus from WT, but not from TRPV4KO mice using the TRPV4N antibody (Fig. 1E). The in situ hybridization results (Fig. $1 B$ ) suggest that both hippocampal neurons and astrocytes express TRPV4 because the TRPV4 mRNA signals were detected in the whole hippocampal regions. High magnification imaging of the hippocampus showed that some of the glia-like cells with large nuclei were TRPV4 positive and stained with antiGFAP antibody (supplemental Fig. $1 D, E$, available at www. jneurosci.org as supplemental material). Interestingly, only a small population of granule neurons and glia-like cells were TRPV4 positive (supplemental Fig. $1 D$, available at www. jneurosci.org as supplemental material), consistent with the following observations (Table 1).

To confirm TRPV4 expression in astrocytes [which appeared to express TRPV4 mRNA (Fig. $1 B$; supplemental Fig. $1 D, E$, available at www.jneurosci.org as supplemental material)], dissociated astrocytes from neonatal hippocampi were cultured, and $>95 \%$ of those cells were confirmed to be astrocytes. Importantly, TRPV4 mRNA expression in cultured neurons and astrocytes was confirmed by RT-PCR (supplemental Fig. $1 F$, available at www. jneurosci.org as supplemental material). Thus, we conclude that both hippocampal neurons and astrocytes express TRPV4.

Compared with in vivo studies, hippocampal neuron cultures are useful for examining the physiological roles of TRPV4, be- 


\begin{tabular}{lll}
\hline & Pyramidal neurons & Granule neurons \\
\hline Calcium imaging by heat application (in wild-type neurons) & $186 / 347(53.6 \%)$ & $124 / 254(48.8 \%)$ \\
Staining (TRPV4 mRNA + GAD65 staining) & $88 / 136(64.3 \%)$ & $105 / 211(49.8 \%)$ \\
\hline
\end{tabular}

The TRPV4-expressing ratio was represented as the responded or TRPV4-positive cells/total cell numbers of each cell type. The pyramidal neurons were identified by morphology and as GAD65-negative neurons.
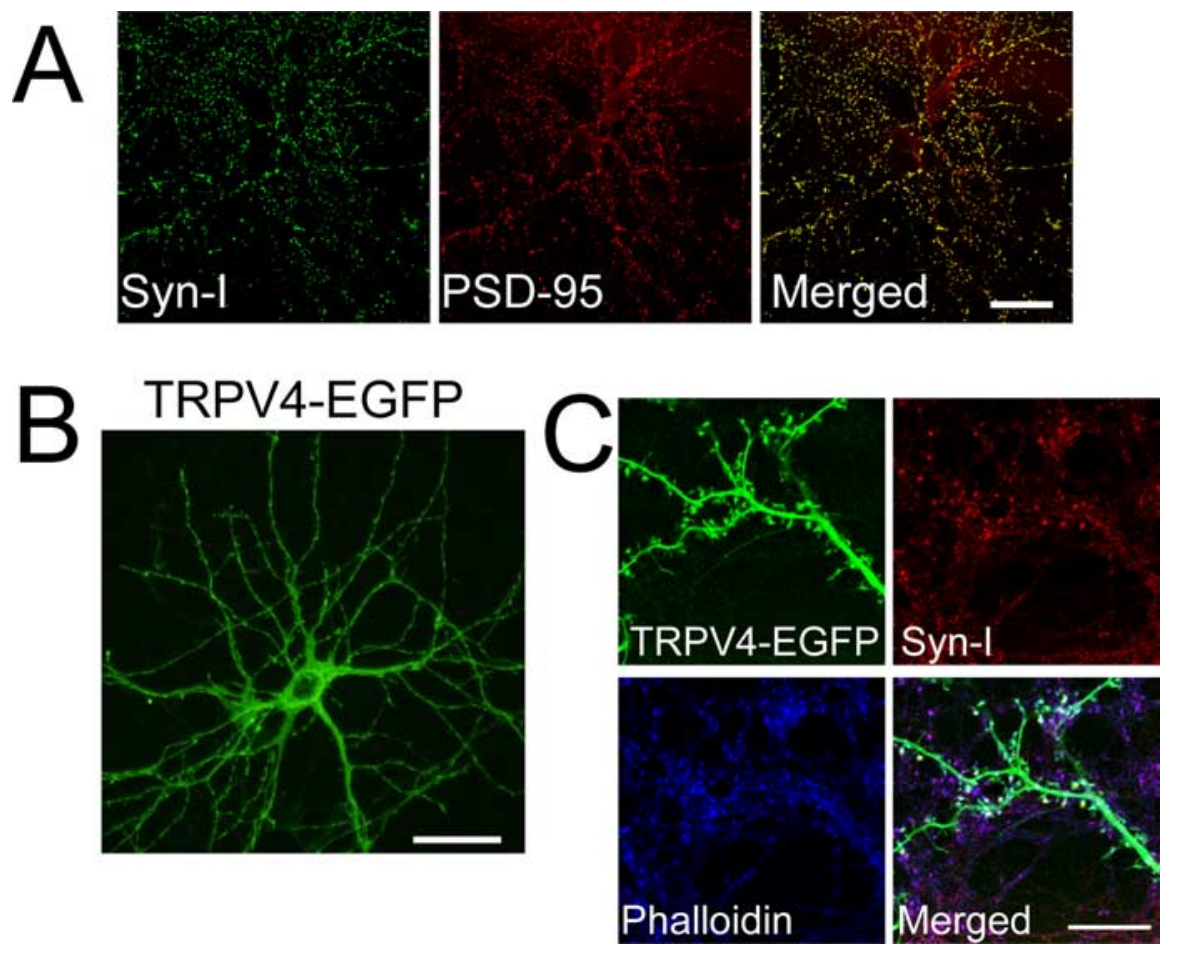

Figure 2. TRPV4-EGFP localized at postsynapses in matured hippocampal neurons. $\boldsymbol{A}$, Synapsin-I (green) and PSD-95 (red) were colocalized in dissociated hippocampal neurons from WT mice at 21 DIV (yellow in a merged image). $\boldsymbol{B}$, Exogenous TRPV4 (green) was localized in the soma (except nucleus) and dendrites of cultured WT hippocampal neurons at 21 DIV ( $2 \mathrm{~d}$ after transfection of EGFP-fused TRPV4, TRPV4-EGFP). C, Exogenous TRPV4 (green) was colocalized with synapsin-I (red) and phalloidin (blue) in spines of cultured WT hippocampal neurons. Scale bars, $50 \mu \mathrm{m}$.

cause neurons can be analyzed in the comparative absence of astrocytes. Thus, we established a dissociated neural culture system from neonatal mice hippocampi to examine TRPV4 functions in hippocampal neurons without the effects of TRPV4 in astrocytes. In the hippocampal neuron culture, we confirmed that $>95 \%$ cells were neurons. In contrast, there are three to four times more glial cells than neurons in vivo. We could observe neural maturation for up to 3 weeks in the culture (Fig. $1 F$ ), in which $\sim 60 \%$ of hippocampal neurons expressed TRPV 4 mRNA at 21 DIV (Table 1; Fig. $1 G$, arrowheads). No TRPV4 mRNA was detected in the dissociated neural culture from TRPV4KO hippocampus (supplemental Fig. $1 C$, available at www.jneurosci.org as supplemental material). Depending on the duration of cultivation, synaptic protein clustering (postsynaptic marker PSD-95 and presynaptic marker synapsin-I) was observed in the cultures, suggesting normal formation of mature synaptic structures (Fig. $2 A)$. Furthermore, synaptic currents became prominent at 21 DIV (data not shown). Characteristics such as dendritic morphology, synaptic marker clustering, and membrane current properties of our cultured hippocampal neurons (Figs. 2, 5, and data not shown) closely matched those of established rat culture hippocampal neurons (Goslin et al., 1998; Lim et al., 2000).

Next, we examined where TRPV4 protein was localized in the cultured hippocampal neurons. Unfortunately, neither commercial TRPV4 antibody (Alomone Labs) nor our own TRPV4N antibody was suitable for immunohistochemical analysis of hippocampal tissues. Therefore, we expressed EGFPfused TRPV4 (TRPV4-EGFP) ectopically in cultured hippocampal neurons at 19 DIV, and observed the EGFP localization at 21 DIV to examine the cellular localization of TRPV4. In preliminary trials, we examined the targeting of TRPV4-EGFP in HEK293 cells by ectopic expression. TRPV4-EGFP signals were predominantly found in the endoplasmic reticulum (data not shown), suggesting that these cells lacked endogenous sorting pathways for the channel (Shibasaki et al., 2004; Arniges et al., 2006). However, in hippocampal neurons, TRPV4-EGFP signals were targeted to the dendrites (Fig. $2 B$ ), suggesting that cultured neurons possessed the endogenous sorting pathway for TRPV4. At high magnification, TRPV4-EGFP signals were observed in both dendritic shafts and spines in addition to the soma (Fig. $2 B, C)$, and colocalized with synapsin-I and phalloidin (Fig. 2C), suggesting that TRPV4 might be localized at postsynapses.

\section{Functional TRPV4 is expressed in hippocampal neurons}

TRPV4 is a thermosensitive ion channel activated at temperatures approaching the physiological core body temperature $\left(>34^{\circ} \mathrm{C}\right)$ (Guler et al., 2002). Using cultured WT murine hippocampal neurons (21 DIV), $\mathrm{Ca}^{2+}$ imaging with fura-2 was assessed to determine whether functional TRPV4 was expressed. An artificial heat ramp (from room temperature to 40 or $50^{\circ} \mathrm{C}$ ) was used to investigate the contribution of temperatures to TRPV4 function, although core body temperature does not normally change $>2-3^{\circ} \mathrm{C}$ in homeothermic animals (Davson, 1951). On application of the heat ramp to hippocampal neurons, an increase in cytosolic $\mathrm{Ca}^{2+}\left(\left[\mathrm{Ca}^{2+}\right]_{\mathrm{i}}\right)$ was observed at $\sim 33^{\circ} \mathrm{C}$, and $\left[\mathrm{Ca}^{2+}\right]_{\mathrm{i}}$ returned to basal level on cooling (Fig. $3 \mathrm{~A}$ ). Increased $\left[\mathrm{Ca}^{2+}\right]_{\mathrm{i}}$ was not observed in the absence of extracellular $\mathrm{Ca}^{2+}$ or in the presence of ruthenium red (a general TRP channel inhibitor; $10 \mu \mathrm{M}$ ) (data not shown), suggesting that $\mathrm{Ca}^{2+}$ influx through TRP channels caused the $\left[\mathrm{Ca}^{2+}\right]_{\mathrm{i}}$ increase. We applied the heat stimulus up to $50^{\circ} \mathrm{C}$ to hippocampal neurons from WT and TRPV4KO mice. Heat-evoked responses were observed in the WT neurons, but not in the TRPV4KO cells (Fig. $3 B, C$ ), confirming that the heat-evoked $\left[\mathrm{Ca}^{2+}\right]_{\mathrm{i}}$ increase in hippocampal neurons $\left(>33^{\circ} \mathrm{C}\right)$ is attributable to TRPV4 expression, and suggesting no functional TRPV1 (temperature threshold, $>43^{\circ} \mathrm{C}$ ) (Caterina et al., 1997) expression in the hippocampus. 
To further assess the involvement of TRPV4 in the heat-evoked responses, we performed patch-clamp experiments using the isolated hippocampal neurons. The heat stimulus activated inward currents at $-60 \mathrm{mV}$ in WT neurons at $\sim 33^{\circ} \mathrm{C}$ $(21.5 \pm 1.3 \mathrm{pA} / \mathrm{pF} ; n=5)$ (Fig. $3 D)$ with an outwardly rectifying current-voltage relationship (Fig. 3E), typical properties reported for heat-evoked currents in the cloned TRPV4 (Guler et al., 2002; Watanabe et al., 2002b). Those results suggest that the heat-evoked responses occur through TRPV4 activation.

Interestingly, some of the hippocampal neurons did not respond to the heat stimulus (Fig. 3A,B), consistent with the TRPV4 mRNA expression pattern (Fig. $1 G)$. We quantified the heat-sensitive populations in $\mathrm{Ca}^{2+}$-imaging experiments, and compared it with TRPV4 mRNA-positive populations in the in situ hybridization analysis (Table 1 ). The proportion of TRPV4 mRNA-positive neurons $(64.3 \%$ of the pyramidal neurons) was similar to that of heat-sensitive cells (53.6\%) (Table 1), further suggesting that TRPV4 was involved in the heat-evoked responses in hippocampal pyramidal neurons.

Next, we examined whether hippocampal neurons responded to other reported TRPV4 stimuli. When a hypotonic stimulus (250 $\mathrm{mOsm} / \mathrm{kg}$; compared with the control isotonic value, 322 $\mathrm{mOsm} / \mathrm{kg}$ ) was applied to WT and TRPV4KO neurons (21 DIV) at $25^{\circ} \mathrm{C}$, a $\left[\mathrm{Ca}^{2+}\right]_{\mathrm{i}}$ increase was observed in WT, but not in TRPV4KO neurons (Fig. $4 A$ ). Increased $\left[\mathrm{Ca}^{2+}\right]_{\mathrm{i}}$ was also observed with $4 \alpha$-PDD (a specific ligand for TRPV4) application in WT neurons at $25^{\circ} \mathrm{C}$, but not in TRPV4KO cells (Fig. $4 \mathrm{~B}$ ). Furthermore, the $4 \alpha$-PDD-evoked $\left[\mathrm{Ca}^{2+}\right]_{\mathrm{i}}$ increase was almost completely inhibited by a TRP channel inhibitor, ruthenium red (Fig. $4 B$ ). $4 \alpha$-PDD-induced whole-cell current activation with an outward rectification was observed in hippocampal neurons from WT, but not from TRPV4KO cells (Fig. 4C-E). The $4 \alpha$-PDD-induced $\left[\mathrm{Ca}^{2+}\right]_{\mathrm{i}}$ increase was observed in acutely dissociated hippocampal neurons similar to cells in the 21 DIV culture (Fig. $4 F$ ), suggesting that long culture condition does not affect TRPV4 expression and that properties of our culture system resemble those found in vivo. When we applied $5 \mathrm{mM}$ camphor (a ligand of TRPV3, whose temperature threshold for activation is $32 \sim 39^{\circ} \mathrm{C}$ similar to that for TRPV4) to WT neurons, no cells responded to the camphor, suggesting no functional expression of TRPV3 in hippocampal neurons (supplemental Fig. 3, available at www.jneurosci.org as supplemental material). Thus, we conclude that functional TRPV4 is predominantly expressed in hippocampal neurons and is activated by physiological body temperature, which causes cation influx in hippocampal neurons.

\section{Hippocampal neurons from TRPV4KO mice do not exhibit significant morphological differences}

We proposed that hippocampal TRPV4 might contribute to synaptic functions. Therefore, WT and TRPV4KO hippocampal neurons were compared with regard to morphology, synaptic
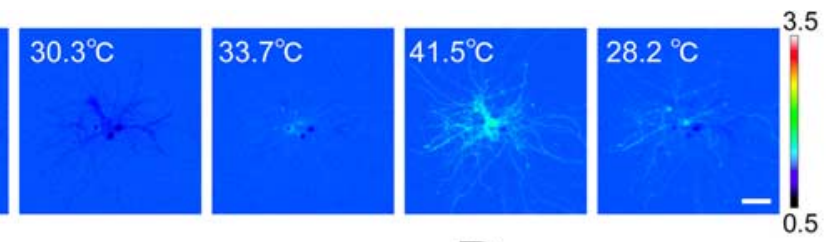

D
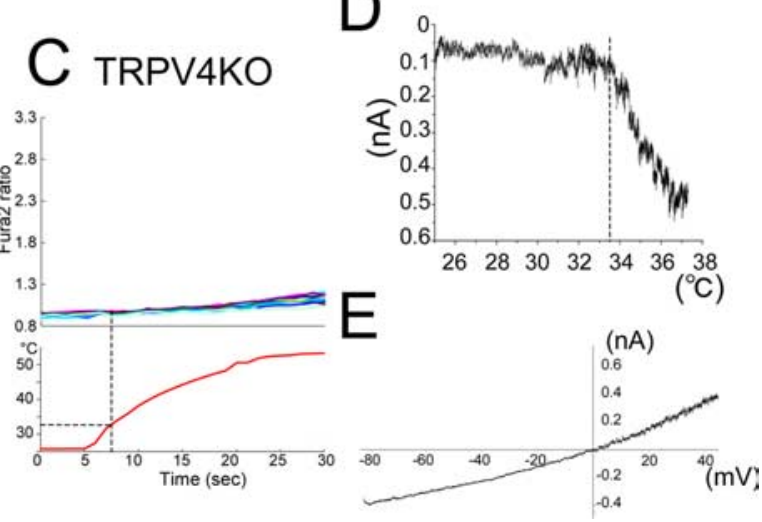
$\ln (\ln )$

Figure 3. Heat-evoked responses in hippocampal pyramidal neurons. $\boldsymbol{A}$, Change in cytosolic $\mathrm{Ca}^{2+}$ concentration $\left(\left[\mathrm{Ca}^{2+}\right]_{\mathrm{i}}\right)$ indicated by the fura- 2 ratio with pseudocolor expression in response to heat stimulation in hippocampal neurons (21 DIV). Scale bar, $50 \mu \mathrm{m}$. These images are representative of six independent cultures $(n=146)$. $\boldsymbol{B}, \boldsymbol{C}$, Representative traces of heat-induced

marker clustering, and synaptic currents. Histological analyses of the hippocampus by hematoxylin-eosin staining did not reveal any differences between WT and TRPV4KO mice (Fig. 5A,B). Ectopic EGFP transfection into cultured hippocampal neurons was performed at $19 \mathrm{DIV}$, and spine density and dendritic branching were quantified at 21 DIV. The morphology of WT pyramidal cells was not significantly different from that of TRPV4KO cells (Fig. 5C,D). We did not detect any significant changes in either spine density [14.2 \pm 1.2 (wild-type) vs $15.1 \pm 1.8$ (TRPV4KO); $n=178-244]$ or dendritic branching [ $8.7 \pm 1.2$ (wildtype) vs $7.8 \pm 2.1$ (TRPV4KO); $n=178-244]$ on loss of TRPV4 expression. Clustering of PSD-95 and synapsin-I was also indistinguishable when WT and TRPV4KO hippocampal sections were compared (data not shown), and the clustering numbers of PSD-95, synapsin-I, and NR1, an NMDA receptor subunit were not significantly different between WT and TRPV4KO hippocampal neurons (Fig. $5 E-G$ ), suggesting that synaptic maturation occurs normally in TRPV4KO hippocampal neurons compared with WT.

To clarify whether TRPV4 expression affected synaptic transmission, we examined miniature EPSC (mEPSC) in WT and TRPV4KO neurons at $25^{\circ} \mathrm{C}$ without activation of TRPV4, because we assumed that we could detect any differences of neurotransmitter release caused by possible changes in TRPV4mediated presynaptic maturation. Compared with WT, mEPSC in TRPV4KO neurons did not exhibit significant differences in amplitudes [10.6 $\pm 0.5 \mathrm{pA}$ (wild-type) vs $11.2 \pm 0.8 \mathrm{pA}$ (TRPV4KO); $n=8$ ]. Similarly, no differences were found in comparisons of frequencies $[6.1 \pm 0.4 \mathrm{~Hz}$ (wild-type) vs $6.4 \pm 0.6$ $\mathrm{Hz}$ (TRPV4KO); $n=8$ ]. These data indicate that presynaptic maturation occurred normally in both WT and TRPV4KO neurons, consistent with the results of synapsin-I clustering. All of these data suggest that functional synapses developed normally both in WT and TRPV4KO neurons at 21 DIV. 
A

hypotonic response
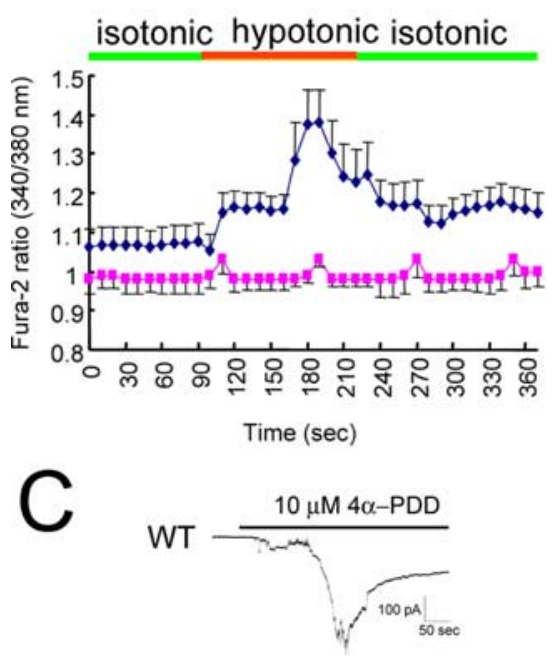

TRPV4KO

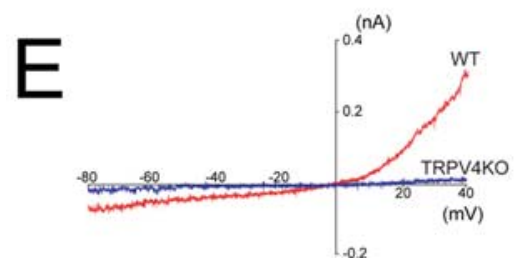

Figure 4. Functional TRPV4 is expressed in hippocampal neurons. $A$, Averaged traces of $\left[\mathrm{Ca}^{2+}\right]_{\mathrm{i}}$ changes (with SEM) on hypotonic stimulus (250 m0sm/kg from isotonic condition; $322 \mathrm{m0sm} / \mathrm{kg}$ ) in WT (blue) and TRPV4KO (red) neurons (21 DIV; 4 independent experiments; $n=156-193)$ at $25^{\circ} \mathrm{C} . \boldsymbol{B}$, Averaged traces of $\left[\mathrm{Ca}^{2+}\right]_{\mathrm{i}}$ changes with $4 \alpha-\operatorname{PDD}(10 \mu \mathrm{M})$ application in WT (blue) and TRPV4KO (red) neurons (21 DIV; 4 independent experiments; $n=161-199)$ at $25^{\circ} \mathrm{C}$. Ruthenium red (10 $\left.\mu \mathrm{M}\right)$ almost completely inhibited $4 \alpha$-PDD-evoked $\left[\mathrm{Ca}^{2+}\right]_{\mathrm{i}}$ increase. $\boldsymbol{C}, \boldsymbol{D}$, Representative current traces on $4 \alpha$-PDD application in WT $(\boldsymbol{C})$ or TRPV4KO (D) neurons (21 DIV). Holding potential was - $60 \mathrm{mV}$. E, Representative current-voltage relationship of $4 \alpha$-PDD-evoked currents in WT (red) and TRPV4KO (blue) neurons (21 DIV). $\boldsymbol{F}$, Averaged traces of $\left[\mathrm{Ca}^{2+}\right]_{\mathrm{i}}$ c changes on $4 \alpha$-PDD (10 $\mu \mathrm{M}$ ) application in acutely dissociated neurons from WT (blue) and TRPV4KO (red) mice (4 independent experiments; $n=814$ ) at $25^{\circ} \mathrm{C}$. Ruthenium red $(10 \mu \mathrm{m})$ almost completely inhibited $4 \alpha$-PDD-evoked $\left[\mathrm{Ca}^{2+}\right]_{\mathrm{i}}$ increase. Green and orange bars in $\boldsymbol{A}, \boldsymbol{B}$, and $\boldsymbol{F}$ indicate application time of the indicated stimuli or compounds.

\section{TRPV4 activation at body temperature leads to} depolarization of resting membrane potential

Because maturation and synaptic currents of hippocampal neurons seemed to be normal in TRPV4KO mice (Fig. 5), it was important to determine the physiological relevance of TRPV4 expression in hippocampal neurons. Given the fact that TRPV4 can be activated at a temperature of $34^{\circ} \mathrm{C}$, we proposed that TRPV4 might be constitutively active in the brain because physiological core body temperature is $\sim 37^{\circ} \mathrm{C}$. If this were correct, TRPV4 activation should cause depolarization of neurons because TRPV4 allows cation influx on its activation. We quantified RMP using a whole-cell patch-clamp method, both at 25 and $37^{\circ} \mathrm{C}$. To identify hippocampal pyramidal neurons, we added Lucifer yellow to the pipette solution, and performed immunostaining with an anti-GAD65 antibody after whole-cell patchclamp recordings. RMP values for WT and TRPV4KO pyramidal neurons were indistinguishable at $25^{\circ} \mathrm{C}(-62.9 \pm 1.8 \mathrm{mV}, n=$ 14 ; and $-61.8 \pm 0.9 \mathrm{mV}, n=14$, respectively) (Fig. $6 A$ ). Temperature elevation (to $37^{\circ} \mathrm{C}$ ) significantly depolarized RMP in both neurons (Fig. 6A). However, the temperature-evoked depolarization was bigger in WT neurons than in TRPV4KO cells
$(-51.1 \pm 1.8 \mathrm{mV}, n=14 ;$ and $-56.8 \pm$ $1.8 \mathrm{mV}, n=14$, respectively; $p<0.001$ ) (Fig. 6A). The difference in RMP at $37^{\circ} \mathrm{C}$ between the two neuronal types $(\sim 5.7$ $\mathrm{mV}$ ) could be attributed to the expression of TRPV4. RMP measurement using a perforated patch-clamp method with nystatin provided essentially the same results (data not shown), indicating that the altered pipette solution did not affect RMP values.

To further confirm the involvement of TRPV4 in RMP formation, we examined the effect of ruthenium red $(10 \mu \mathrm{M})$ on $\mathrm{RMP}$ in WT neurons at $37^{\circ} \mathrm{C}$. Application of ruthenium red significantly hyperpolarized RMP from $-52.0 \pm 0.6$ to $-56.6 \pm 0.7 \mathrm{mV}(n=5 ; p<0.01)$ (Fig. $6 B)$, and the RMP change $(\sim 5.0 \mathrm{mV})$ was almost identical with the RMP differences $(\sim 5.7 \mathrm{mV})$ shown in Figure $6 A$. These results strongly indicate that physiological core body temperature $\left(\sim 37^{\circ} \mathrm{C}\right)$ activates TRPV4, thereby causing depolarization of RMP in the hippocampal neurons. We hypothesized that TRPV4 was activated by physiological temperature and the resulting depolarization of RMP contributed to neural firing.

To test that hypothesis, we observed action potential generation on current injections in WT and TRPV4KO hippocampal neurons. Repetitive firings were observed in WT neurons (RMP, -50.06 $\mathrm{mV}$ ), whereas only a few firings were induced by the same current injection in TRPV4KO cells (RMP, $-55.87 \mathrm{mV}$ ) (Fig. $6 C)$. Significant differences in firing numbers were observed in the wide range of current injections (Fig. 6D). These phenomena indicate that TRPV4KO hippocampal neurons require much bigger current injections to initiate firing. These results suggest that TRPV4 contributes to the excitability of hippocampal neurons at physiological core body temperature through depolarization, although both activation and inactivation of voltage-gated $\mathrm{Na}^{+}$ channels are known to contribute to neuronal excitability.

\section{Heat activation of TRPV4 contributes to activation of NMDA receptors}

We considered the possibility that depolarization of RMP at $37^{\circ} \mathrm{C}$ through TRPV4 activation (Fig. $6 A, B$ ) might be related to activation of NMDA receptors, because activation of NMDA receptors requires depolarization to remove the $\mathrm{Mg}^{2+}$ block (Wollmuth et al., 1998). Threshold potentials for NMDA activation were reported to be -45 to $-50 \mathrm{mV}$, voltages close to the RMP of WT hippocampal neurons at $37^{\circ} \mathrm{C}$ (Fig. $6 \mathrm{~A}$ ). Thus, we proposed that WT hippocampal neurons might reach the threshold for NMDA receptor activation more readily than TRPV4KO cells. First, we examined whether NMDA alone could activate hippocampal neurons in our assay system. NMDA $(50 \mu \mathrm{M})$ failed to increase $\left[\mathrm{Ca}^{2+}\right]_{\mathrm{i}}$ in WT hippocampal neurons at both 25 and $37^{\circ} \mathrm{C}$, indicating that depolarization caused by TRPV4 activation 
at $37^{\circ} \mathrm{C}$ is not sufficient to open NMDA receptor channels (Fig. $7 A$ ). We then hypothesized that TRPV4 activation by physiological body temperature could render hippocampal neurons more susceptible to activation by excitatory stimuli. To explore this hypothesis, we examined glutamate responses in WT and TRPV4KO neurons at different temperatures $\left(25\right.$ or $\left.37^{\circ} \mathrm{C}\right)$. When we performed $\mathrm{Ca}^{2+}$-imaging control experiments, repeated applications of glutamate gave a similar $\left[\mathrm{Ca}^{2+}\right]_{\mathrm{i}}$ increase pattern in the same neuron at both temperatures (supplemental Fig. 4, available at www. jneurosci.org as supplemental material). Next, when we applied glutamate (500 $\mathrm{nm}$ ) to hippocampal neurons at $25^{\circ} \mathrm{C}$, we observed a slow $\left[\mathrm{Ca}^{2+}\right]_{\mathrm{i}}$ increase. However, $\left[\mathrm{Ca}^{2+}\right]_{\mathrm{i}}$ increase was accelerated at $37^{\circ} \mathrm{C}$ in the same culture (Fig. $7 \mathrm{~B}$ ), indicating that glutamate effects were enhanced at $37^{\circ} \mathrm{C}$. When the $\left[\mathrm{Ca}^{2+}\right]_{\mathrm{i}}$ increase was quantified $18 \mathrm{~s}$ after glutamate application (time point reaching the peak $\left[\mathrm{Ca}^{2+}\right]_{\mathrm{i}}$ increase) (supplemental Fig. 4, available at www.jneurosci.org as supplemental material), we found that temperature elevation caused significantly more $\left[\mathrm{Ca}^{2+}\right]_{\mathrm{i}}$ increase in WT hippocampal neurons than in TRPV4KO cells, although there was some significant $\left[\mathrm{Ca}^{2+}\right]_{\mathrm{i}}$ increase on heating in TRPV4KO neurons as well, which can be expected by heat-evoked depolarization through a TRPV4-independent mechanism as shown in Figure $6 A$ (Fig. $7 C$ ). Furthermore, the temperature-dependent $\left[\mathrm{Ca}^{2+}\right]_{\mathrm{i}}$ increase at $37^{\circ} \mathrm{C}$ was significantly inhibited by a NMDA receptor blocker, APV in WT, but not in TRPV4KO neurons, suggesting the involvement of TRPV4 in NMDA receptor-mediated $\left[\mathrm{Ca}^{2+}\right]_{\mathrm{i}}$ increase by glutamate. We already confirmed that the expression of NMDA receptor subunits was not affected in TRPV4KO neurons (Fig. 5G). Thus, the difference in glutamate responses between WT and TRPV4KO neurons at $37^{\circ} \mathrm{C}$ can be attributed to TRPV4 activation.

\section{Discussion}

TRPV4 contributes to temperature-

dependent brain function

The present study analyzes the impact of physiological core body temperature on neural activity at the molecular level. We examined TRPV4 expression in a hippocampal neuron culture system from neonatal mice, and found that hippocam-

pal neurons strongly expressed TRPV4 (Fig. 1). Using the neuron culture system permitted us to significantly reduce the effects of astrocytes (Figs. 1, 2; supplemental Fig. 1, available at www.jneurosci.org as supplemental material). Using $\mathrm{Ca}^{2+}$.
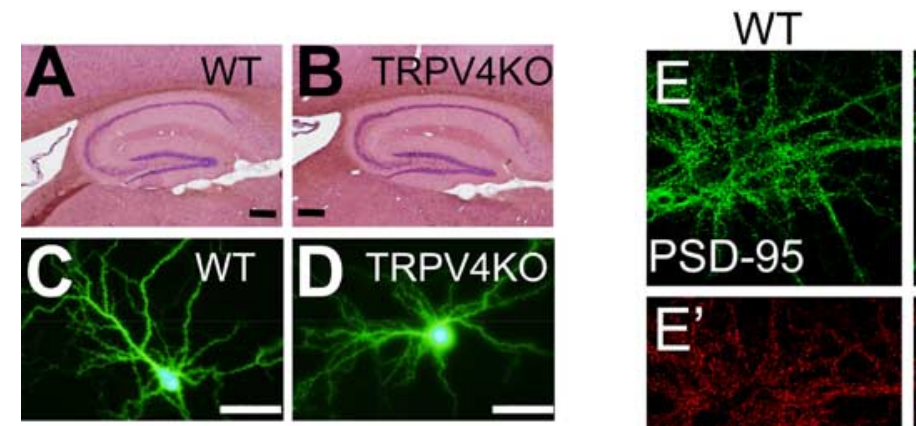

TRPV4KO
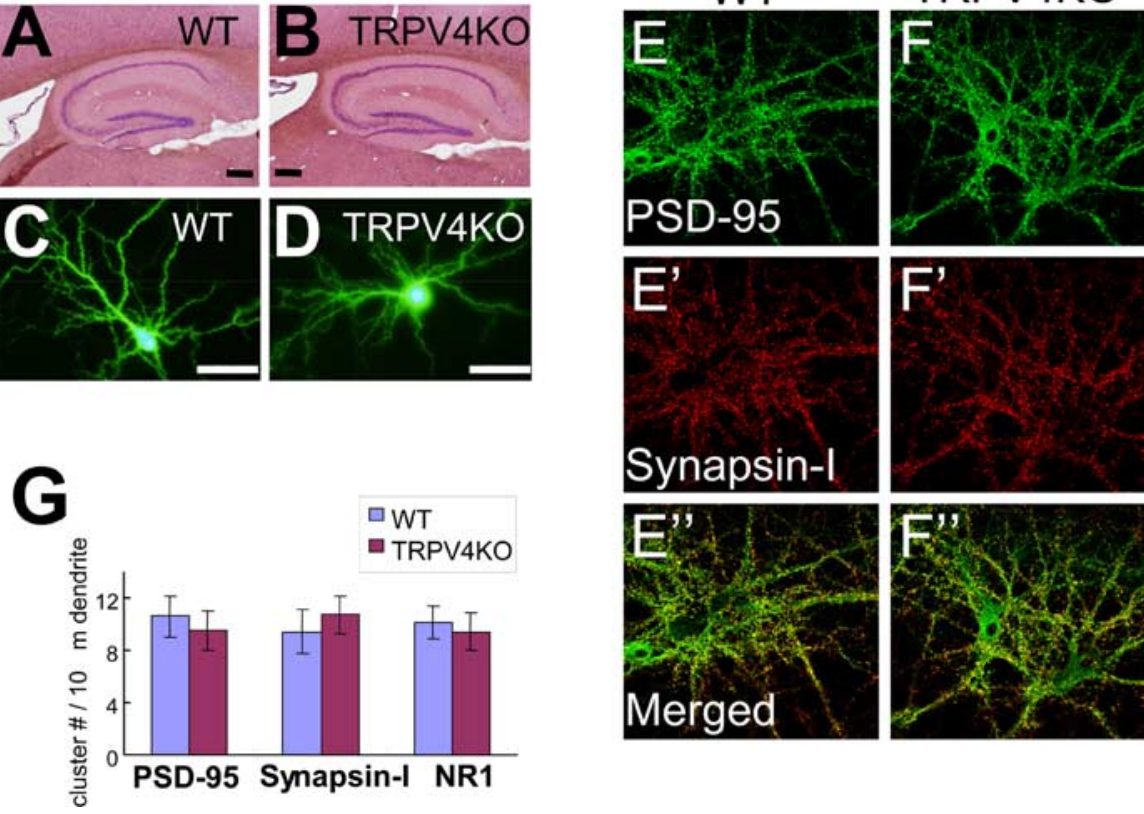

Figure 5. Maturation of TRPV4KO hippocampal neurons is normal. $A, B$, Hematoxylin- eosin staining of sagittal hippocampal sections [8-week-old adult; WT (A); TRPV4KO (B)]. Scale bars, $200 \mu \mathrm{m}$. C, D, Morphology of dissociated hippocampal neurons [WT (C); TRPV4KO (D)] at 21 DIV (EGFP was expressed at 19 DIV). Scale bars, $50 \mu \mathrm{m} . \boldsymbol{E}, \boldsymbol{F}$, Immunostaining of PSD-95 (green) and synapsin-I (red) in dissociated neurons from WT (left) and TRPV4KO (right) at 21 DIV. Scale bar, $50 \mu \mathrm{m}$. G, Quantitative analysis of cluster numbers of PSD-95, synapsin-I, and NR1 in dissociated neurons from WT and TRPV4K0 at 21 DIV. Error bars indicate SEM.
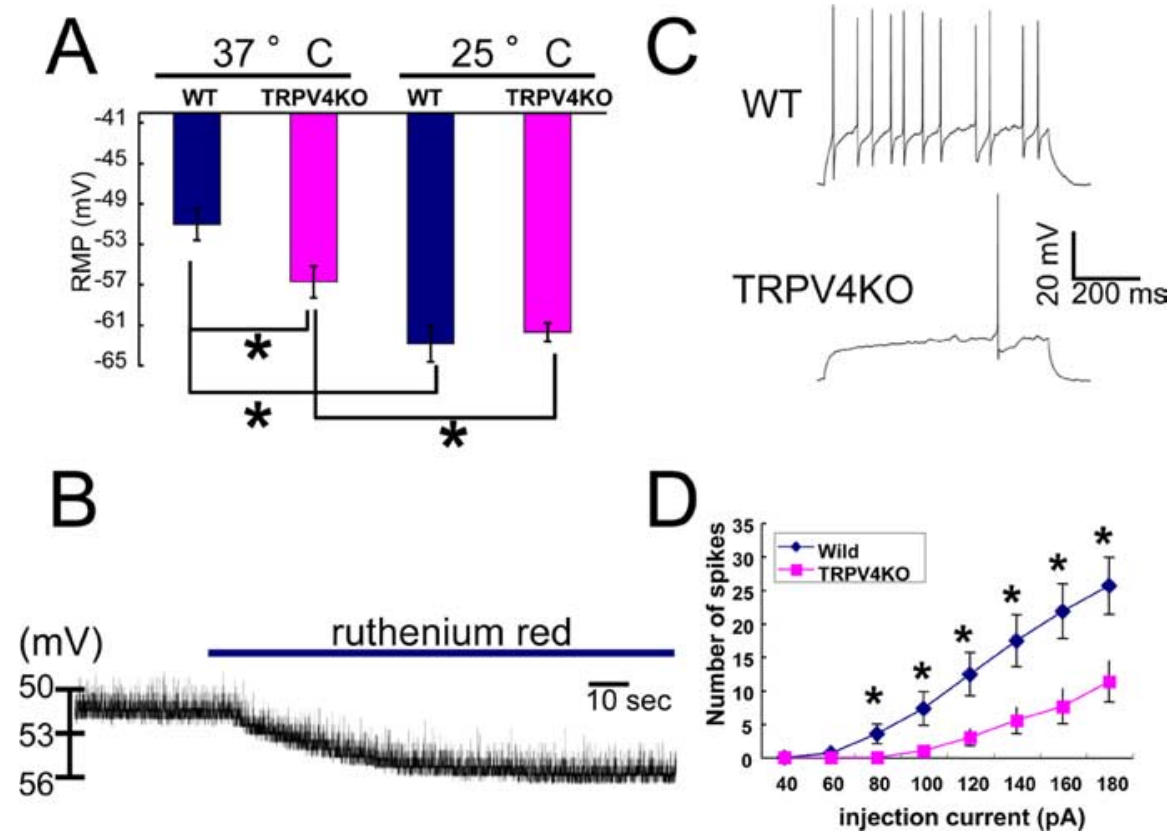

Figure 6. TRPV4 expression is responsible for neural excitability through changes in RMPs in hippocampal pyramidal neurons. $A$, Average RMP (with SEM) at 25 and $37^{\circ} \mathrm{C}$ in WT and TRPV4KO neurons. ${ }^{*} p 0.001(n=14) . \boldsymbol{B}$, A representative trace of RMP change (from -51.13 to $-56.09 \mathrm{mV}$ ) by ruthenium red application (blue bar) at $37^{\circ} \mathrm{C}$ in a WT neuron. C, Representative traces of membrane potentials on current injection $(+100 \mathrm{pA})$ in WT and TRPV4KO neurons at $37^{\circ} \mathrm{C}$. RMP of WT, $-50.06 \mathrm{mV}$; TRPV4K0, $-55.87 \mathrm{mV}$. D, Spike induction with indicated current injections in WT and TRPV4KO neurons at $37^{\circ} \mathrm{C} .{ }^{*} p<0.001(n=22)$.

imaging and whole-cell patch-clamp recordings, we further confirmed the functional expression of TRPV4 (Figs. 3, 4). We found that physiological temperature activates TRPV4 in neurons (Figs. 3,6 ), resulting in depolarization of the RMP in the neurons (Fig. $6)$. This strongly suggests a role of TRPV4 in the temperature- 

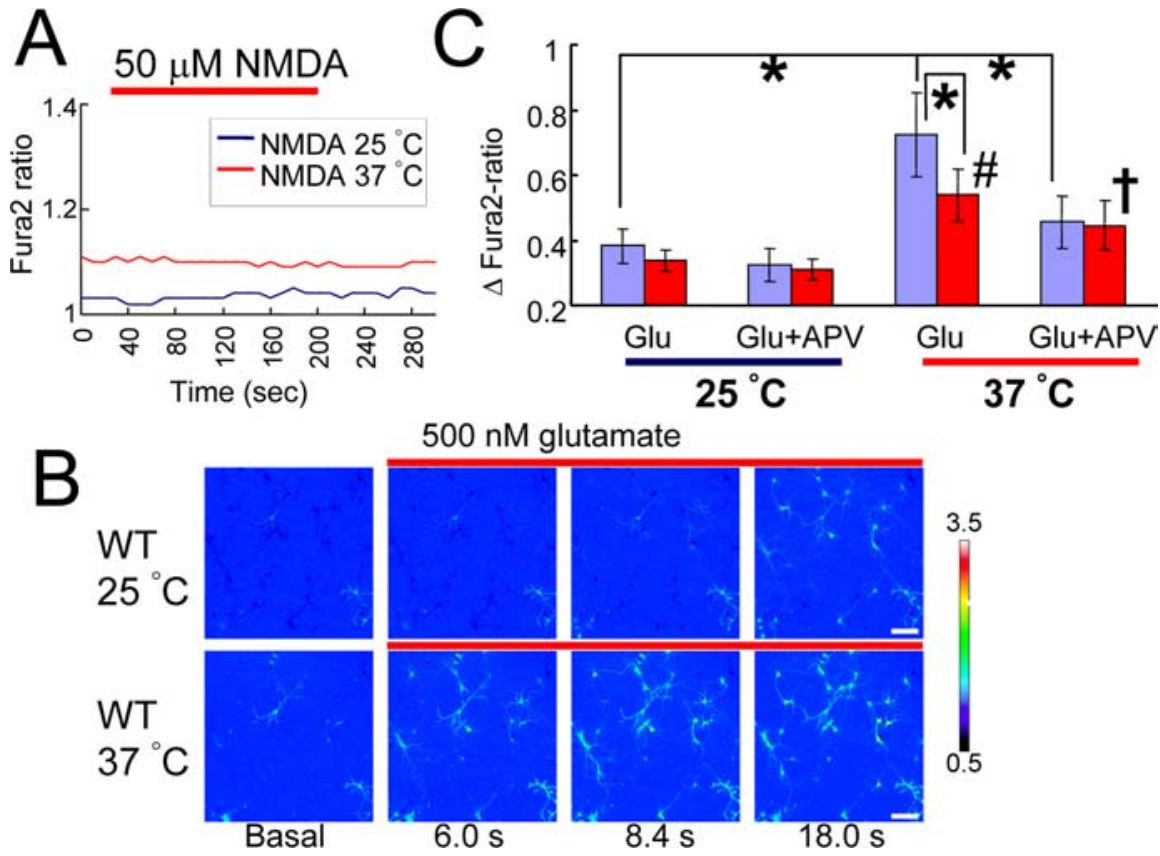

Figure 7. TRPV4 activation at body temperature promotes NMDA receptor activation in hippocampal pyramidal neurons. $\boldsymbol{A}$, Averaged traces of $\left[\mathrm{Ca}^{2+}\right]_{i}$ changes with NMDA $(50 \mu \mathrm{M})$ application (red bar) in WT neurons both at 25 and $37^{\circ} \mathrm{C}(6$ independent experiments; $n=221-246)$. $\boldsymbol{B}$, Changes in $\left[\mathrm{Ca}^{2+}\right]_{i}$ with pseudocolor expression with glutamate (500 nM) application (red bars) at $25^{\circ} \mathrm{C}$ (top) or $37^{\circ} \mathrm{C}$ (bottom) in the WT neurons. Scale bars, $50 \mu \mathrm{m}$. C, Changes in $\left[\mathrm{Ca}^{2+}\right]_{\mathrm{i}}$ ( $\Delta$ Fura2-ratio) at 25 and $37^{\circ} \mathrm{C}$ with glutamate (Glu) (500 nM) application in the presence or absence of APV (50 $\mu \mathrm{M})$ in WT (purple) and TRPV4KO (red) neurons. $\Delta$ Fura2-ratio indicates the difference in $\left[\mathrm{Ca}^{2+}\right]_{\mathrm{i}}$ ratio between basal level and $18 \mathrm{~s}$ after Glu application. The quantification timing can be checked in supplemental Figure 5 (available at www.jneurosci.org as supplemental material). ${ }^{*} p<0.01$ versus each control; ${ }^{\#} p<0.01$ versus Glu at $25^{\circ} \mathrm{C}$ (in TRPV4K0); ${ }^{\dagger} p<0.05$ versus Glu plus APV at $25^{\circ} \mathrm{C}$ (in TRPV4K0) ( 6 independent cultures; $n=206-251)$. Error bars indicate SEM.

dependent regulation of neural activity. The data also revealed that physiological core body temperature-evoked TRPV4 activation affects neural firing through NMDA receptor activation (Figs. 6, 7).

The importance of physiological temperature in brain functions has been studied in the hippocampus (Thompson et al., 1985; Anderson and Moser, 1995; de la Pena et al., 2005), although the molecular mechanisms have not been well clarified. Our findings indicate that TRPV4 activation at physiological core body temperature might partially underlie it. Interestingly, previous studies in humans implied that a temperature of $33^{\circ} \mathrm{C}$ is critical because cooling below this temperature affected cognitive function (Fay and Smith, 1941). It was also examined whether different brain temperatures $\left(38.4,34.7,31.8\right.$, or $\left.28.4^{\circ} \mathrm{C}\right)$ affected rat hippocampal functions in acquisition and maintenance of spatial learning tasks (Moser and Andersen, 1994). In the watermaze task, changes in field potential were already significant at $34.7^{\circ} \mathrm{C}$, although no change in the ability to learn hiddenplatform location was observed until brain temperature was reduced to $28.4^{\circ} \mathrm{C}$, suggesting that some brain functions are affected at a temperature of $34.7^{\circ} \mathrm{C}$. The temperatures of 33 and $34.7^{\circ} \mathrm{C}$ closely match the temperature threshold for TRPV4 activation in hippocampal neurons, which we observed in both $\mathrm{Ca}^{2+}$-imaging and whole-cell patch-clamp recordings (Fig. 3), suggesting that TRPV4 activation might be related to brain functions. In our preliminary observations, basal behaviors (locomotion activity, sleep, food intake, and reproductivity) of TRPV4KO mice seemed to be normal. Additional behavioral analyses including learning and memory functions will be pursued to reveal the possible involvement of TRPV4 in brain activities. Addition- ally, information from slice patch-clamp recordings would be informative. However, a temperature of $33^{\circ} \mathrm{C}$ is generally preferred to $37^{\circ} \mathrm{C}$ for slice patch-clamp recordings of brain tissues because oxygen consumption is suppressed at the lower temperatures, suggesting that slice patchclamp recordings might provide different outcomes compared with the recordings obtained with dissociated neurons, the method that we used in the present study.

\section{How heat-evoked TRPV4 can be involved in neural activity}

The CA3 region expressed TRPV4 mRNA at higher levels than did other brain regions (Fig. 1). Aihara et al. (2001) reported that hypothermic treatment (from 35 to $25^{\circ} \mathrm{C}$ ) of $\mathrm{CA} 3$ hippocampal pyramidal neurons reduced the EPSP slope in a temperature-dependent manner, and that neuronal activities including membrane properties fully recovered when the temperature was returned to $35^{\circ} \mathrm{C}$ even from as low as $15^{\circ} \mathrm{C}$. Temperature-dependent reciprocal changes in hippocampal field activity were also reported (Karlsson and Blumberg, 2004). In that study, the authors recorded spontaneous hippocampal activity along the rat CA1-dentate gyrus axis using multisite silicon electrodes at brain temperatures of 27 and $37^{\circ} \mathrm{C}$. Theta and gamma activities were detected at $37^{\circ} \mathrm{C}$, but not at $27^{\circ} \mathrm{C}$. This result might be partially explained by TRPV4-mediated depolarization and firing, which we observed in hippocampal neurons (Fig. 6), although oxygen consumption could be involved at this temperature as well. Together, TRPV4 activation might be one of the critical determinants for a wide range of temperature-dependent functions in the hippocampus.

We have hypothesized that physiological temperature provides the optimal thermal environment for TRPV4 activation in hippocampal neurons such that their firing causes significant depolarization close to the potential threshold for NMDA receptor activation (Wollmuth et al., 1998). Consistent with our results, it has been recently reported that increases in physiological temperature accelerate the kinetics and increase the amplitude of EPSC in different neural tissues including hippocampus, brainstem, and retina (Gasparini et al., 2000; Taschenberger and von Gersdorff, 2000; Groc et al., 2002; Veruki et al., 2003). In their results, the enhancement of EPSC by physiological temperature was thought to be caused by potentiation of glutamate receptors. In our study, the RMP of hippocampal neurons was significantly depolarized and glutamate-induced $\left[\mathrm{Ca}^{2+}\right]_{\mathrm{i}}$ increase was accelerated on heating from 25 to $37^{\circ} \mathrm{C}$. Increased activities of both TRPV4 and glutamate receptors could be involved in our results, although heat-evoked TRPV4-mediated inward currents made it difficult to examine the heat effects on EPSC properties in our study. Because we observed significant heat-evoked, TRPV4independent depolarization and glutamate-induced $\left[\mathrm{Ca}^{2+}\right]_{\mathrm{i}}$ increase (Figs. 6, 7), physiological temperature might affect many different factors including TRPV4, glutamate receptors, oxygen consumption, enzyme activities, and Brownian movement of molecules. 


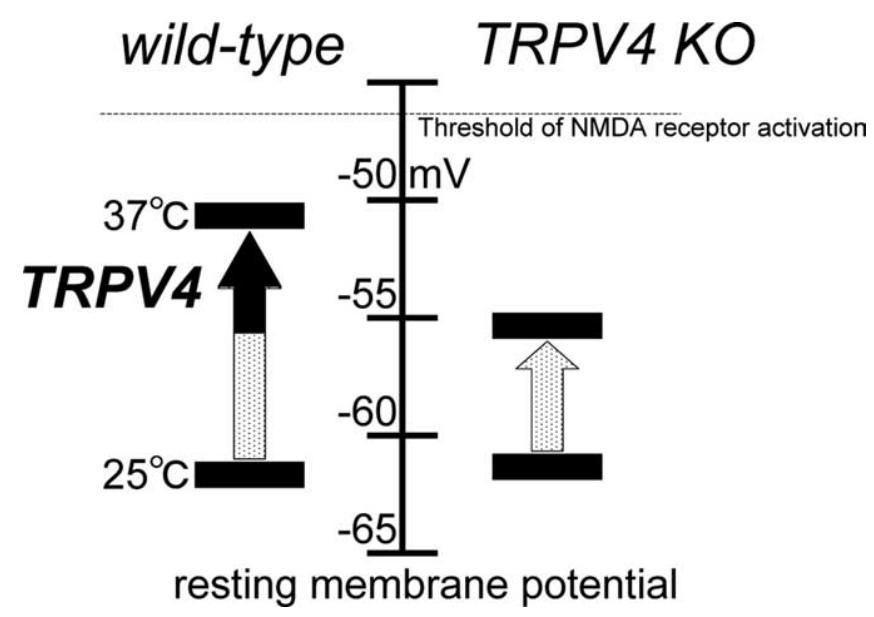

Figure 8. A proposed model for TRPV4 involvement in the regulation of RMPs in hippocampal pyramidal neurons. RMPs were not significantly different between wild-type and TRPV4KO neurons at approximately $-62 \mathrm{mV}$ at $25^{\circ} \mathrm{C}$. RMPs were significantly depolarized to a value close to the threshold for NMDA receptor activation in wild-type neurons compared with TRPV4KO at $37^{\circ} \mathrm{C}$, leading to more excitability.

We conclude that activation of TRPV4 at physiological body temperature is one of the underlying molecular mechanisms by which physiological temperature enhances neural activity compared with that observed at room temperature (Fig. 8). The TRPV4-mediated component is not the sole explanation for physiological temperature-evoked depolarization of RMP (Figs. $6 A, 8)$. However, the $5 \mathrm{mV}$ differences between RMPs observed in WT and TRPV4KO hippocampal neurons could be critical for their excitability because the observed RMP of WT hippocampal neurons is close to the reported potential threshold for NMDA receptor activation and because hippocampal neurons are exposed to many excitatory stimuli. Thus, our findings provide the possibility that the thermosensitive TRP channel, TRPV4, is a molecular transducer of physiological temperature information in the hippocampus, and has a physiological impact on neural activities (Fig. 8). Interestingly, hippocampal astrocytes also express TRPV4. Therefore, it is intriguing to speculate that hippocampal neural functions might be regulated by many different mechanisms through TRPV4 functions expressed in neurons and astrocytes.

\section{References}

Aihara H, Okada Y, Tamaki N (2001) The effects of cooling and rewarming on neural activity of pyramidal neurons in guinea pig hippocampal slices. Brain Res 893:36-45.

Alessandri-Haber N, Yeh JJ, Boyd AE, Parada CA, Chen X, Reichiling DB, Levine JD (2003) Hypotonicity induces TRPV4-mediated nociception in rat. Neuron 39:497-511.

Anderson P, Moser EI (1995) Brain temperature and hippocampal function. Hippocampus 5:491-498.

Arniges M, Fernandez-Fernandez JM, Albrecht N, Schaefer M, Valverde MA (2006) Human TRPV4 channel splice variants revealed a key role of ankyrin domains in multimerization and trafficking. J Biol Chem 281:1580-1586.

Caterina MJ, Schumacher MA, Tominaga M, Rosen TA, Levine JD, Julius D (1997) The capsaicin receptor: a heat activated ion channel in the pain pathway. Nature 389:816-824.

Davson H (1951) A textbook of general physiology. New York: McGraw Hill.

Delany NS, Hurle M, Facer P, Alnadaf T, Plumpton C, Kinghorn I, See CG, Costigan M, Anand P, Woolf CJ, Crowther D, Sanseau P, Tate SN (2001) Identification and characterization of a novel human vanilloid receptorlike protein, VRL-2. Physiol Genomics 4:165-174.

de la Pena E, Malkia A, Cabedo H, Belmonte C, Viana F (2005) The contri- bution of TRPM8 channels to cold sensing in mammalian neurones. J Physiol (Lond) 567:415-426.

Fay T, Smith GW (1941) Observations on reflex responses during prolonged periods of human refrigeration. Arch Neurol Psychiatry 45:215-222.

Gasparini S, Saviane C, Voronin LL, Cherubini E (2000) Silent synapses in the developing hippocampus: lack of functional AMPA receptors or low probability of glutamate release? Proc Natl Acad Sci USA 97:9741-9746.

Goslin K, Asmussen H, Banker G (1998) Rat hippocampal neurons in lowdensity culture. In: Culturing nerve cells, Ed 2 (Goslin K, Banker G, eds), pp 339-370. Cambridge, MA: MIT.

Groc L, Gustafsson B, Hanse E (2002) Spontaneous unitary synaptic activity in CA1 pyramidal neurons during early postnatal development: constant contribution of AMPA and NMDA receptors. J Neurosci 22:5552-5562.

Guler AD, Lee H, Iida T, Shimizu I, Tominaga M, Caterina M (2002) Heatevoked activation of the ion channel, TRPV4. J Neurosci 22:6408-6414.

Hodgkin AI, Katz B (1949) The effect of temperature on the electrical activity of the giant axon of the squid. J Physiol (Lond) 109:240-249.

Karlsson KA, Blumberg MS (2004) Temperature-induced reciprocal activation of hippocampal field activity. J Neurophysiol 91:583-588.

Liedtke W, Friedman JM (2003) Abnormal osmotic regulation in trpv4-/mice. Proc Natl Acad Sci USA 100:13698-13703.

Liedtke W, Choe Y, Marti-Renom MA, Bell AM, Denis CS, Sali A, Hudspeth AJ, Friedman JM, Heller S (2000) Vanilloid receptor-related osmotically activated channel (VR-OAC), a candidate vertebrate osmoreceptor. Cell 103:525-535.

Lim ST, Antonucci DE, Scannevin RH, Trimmer JS (2000) A novel targeting signal for proximal clustering of the $\mathrm{Kv} 2.1 \mathrm{~K}^{+}$channel in hippocampal neurons. Neuron 25:385-397.

Malenka RC, Nicoll RA (1999) Long-term potentiation-a decade of progress? Science 285:1870-1874.

Maletic-Savatic M, Lenn NJ, Trimmer JS (1995) Differential spatiotemporal expression of $\mathrm{K}^{+}$channel polypeptides in rat hippocampal neurons developing in situ and in vitro. J Neurosci 15:3840-3851.

Marinelli S, Marzo VD, Berretta N, Matias I, Maccarrone M, Bernardi G, Mercuri NB (2003) Presynaptic facilitation of glutamatergic synapses to dopaminergic neurons of the rat substantia nigra by endogenous stimulation of vanilloid receptors. J Neurosci 23:3136-3144.

Mizuno A, Matsumoto N, Imai M, Suzuki M (2003) Impaired osmotic sensation in mice lacking TRPV4. Am J Physiol 285:C96-C101.

Moser E, Mathiesen I, Andersen P (1993) Association between brain temperature and dentate field potentials in exploring and swimming rats. Science 259:1324-1326.

Moser EI, Andersen P (1994) Conserved spatial learning in cooled rats in spite of slowing of dentate field potentials. J Neurosci 14:4458-4466.

Mutai H, Heller S (2003) Vertebrate and invertebrate TRPV-like mechanoreceptor. Cell Calcium 33:471-478.

Nicholls JG, Martin RG, Wallace BG, Fuchs PA (2001) From neuron to brain, Ed 4, pp 25-225. Sunderland, MA: Sinauer Associates.

Nicoll RA (2003) Expression mechanisms underlying long-term potentiation: a postsynaptic view. Philos Trans R Soc Lond B Biol Sci 358:721-726.

Nilius B, Prenen J, Wissenbach U, Bodding M, Droogmans G (2001) Differential activation of the volume-sensitive cation channel TRP12 (OTRPC4) and volume-regulated anion currents in HEK-293 cells. Pflügers Arch 443:227-233.

Nilius B, Vriens J, Prenen J, Droogmans G, Voets T (2004) TRPV4 calcium entry channel: a paradigm for gating diversity. Am J Physiol 286:C195-C205.

Ritchie JM, Straub RW (1956) The effect of coolingon the size of the action potential of mammalian non-medullated fibers. J Physiol (Lond) 134:712-717.

Schiff SJ, Somjen GG (1985) The effects of temperature on synaptic transmission in hippocampal tissue slices. Brain Res 345:279-284.

Shibasaki K, Nakahira K, Trimmer JS, Shibata R, Akita M, Watanabe S, Ikenaka K (2004) Mossy fibre contact triggers the targeting of Kv4.2 potassium channels to dendrites and synapses in developing cerebellar granule neurons. J Neurochem 89:897-907.

Shibasaki K, Takebayashi H, Ikenaka K, Feng L, Gan L (2007) Expression of the basic helix-loop-factor Olig2 in the developing retina: Olig2 as a new marker for retinal progenitors and late-born cells. Gene Expr Patterns 7:57-65.

Stortmann R, Harteneck C, Nunnenmacher K, Schultz G, Plant TD (2000) 
OTRPC4, a nonselective cation channel that confers sensitivity to extracellular osmolarity. Nat Cell Biol 2:695-702.

Suzuki M, Mizuno A, Kodaira K, Imai M (2003) Impaired pressure sensation in mice lacking TRPV4. J Biol Chem 278:22664-22668.

Taschenberger H, von Gersdorff H (2000) Fine-tuning an auditory synapse for speed and fidelity: developmental changes in presynaptic waveform, EPSC kinetics, and synaptic plasticity. J Neurosci 20:9162-9173.

Thompson SM, Masukawa LM, Prince DA (1985) Temperature dependence of intrinsic membrane properties and synaptic potentials in hippocampal CA1 neurons in vitro. J Neurosci 5:817-824.

Tominaga M, Caterina MJ, Malmberg AB, Rosen TA, Gilbert H, Skinner K, Raumann BE, Basbaum AI, Julius D (1998) The cloned capsaicin receptor integrates multiple pain-producing stimuli. Neuron 21:531-543.

Trimmer JS (1998) Regulation of ion channel expression by cytoplasmic subunits. Curr Opin Neurobiol 8:370-374.

Veruki ML, Morkve SH, Hartveit E (2003) Functional properties of spontaneous EPSCs and non-NMDA receptors in rod amacrine (AII) cells in the rat retina. J Physiol (Lond) 549:759-774.

Watanabe H, Davis JB, Smart D, Jerman JC, Smith GD, Hayes P, Vriens J,
Cairns W, Wissenbach U, Prenen J, Flockerzi V, Droogmans G, Benham CD, Nillius B (2002a) Activation of TRPV4 channels (hVRL-2/ mTRP12) by phorbol derivatives. J Biol Chem 277:13569-13577.

Watanabe H, Vriens J, Suh SH, Benham CD, Droogmans G, Nillius B (2002b) Heat-evoked activation of TRPV4 channels in a HEK293 cell expression system and in native mouse aorta endothelial cells. J Biol Chem 277:47044-47051.

Watanabe H, Vriens J, Prenen J, Droogmans G, Voets T, Nillius B (2003) Anandamide and arachidonic acid use epoxyeicosatrienoic acids to activate TRPV4 channels. Nature 424:434-438.

Wemmie JA, Chen J, Askwith CC, Hruska-Hageman AM, Price MP, Nolan BC, Yoder PG, Lamani E, Hoshi T, Freeman JHJ, Welsh MJ (2002) The acid-activated ion channel ASIC contributes to synaptic plasticity, learning, and memory. Neuron 34:463-477.

Wissenbach U, Bodding M, Freichel M, Flockerzi V (2000) Trp12, a novel Trp related protein from kidney. FEBS Lett 485:127-134.

Wollmuth LP, Kuner T, Sakmann B (1998) Adjacent asparagines in the NR2-subunit of the NMDA receptor channel control the voltagedependent block by extracellular $\mathrm{Mg}^{2+}$. J Physiol (Lond) 506:13-32. 